This is an Accepted Manuscript of an article published by Taylor \& Francis in Medical Teacher, on 28/04/18, available online:

https://www.tandfonline.com/doi/full/10.1080/0142159X.2018.1460656 


\title{
Online Interprofessional Education Facilitation: A Scoping
}

\section{Review}

\author{
Sherryn Evans - Deakin University \\ Catherine Ward - Deakin University \\ Scott Reeves - Kingston University and St George’s, University of London
}

\section{Corresponding Author}

Sherryn Evans, Geelong Waterfront Campus, Deakin University, Locked Bag 20001, Geelong, VIC 3220, Australia. Tel: +61 3 52278437; Fax: +61 3522 78621; E-mail: sherryn.evans@deakin.edu.au 


\title{
Online Interprofessional Education Facilitation: A Scoping Review
}

\begin{abstract}
Introduction: The use of online media to deliver interprofessional education (IPE) is becoming more prevalent across health professions education settings. Facilitation of IPE activities is known to be critical to the effective delivery of IPE, however, specifics about the nature of online IPE facilitation remains unclear.
\end{abstract}

Aim: To explore the health professions education literature to understand the extent, range and nature of research on online IPE facilitation.

Methods: Scoping review methodology was used to guide a search of four electronic databases for relevant papers. Of the 2095 abstracts initially identified, after screening of both abstracts and full-text papers, 10 studies were selected for inclusion in this review. Following abstraction of key information from each study, a thematic analysis was undertaken.

Results: Three key themes emerged to describe the nature of the IPE facilitation literature: (1) types of online IPE facilitation contributions, (2) the experience of online IPE facilitating and (3) personal outcomes of online IPE facilitation. These IPE facilitation themes were particularly focused on facilitation of interprofessional student teams on an asynchronous basis.

Discussion: While the included studies provide some insight into the nature of online IPE facilitation, future research is needed to better understand facilitator contributions, and the facilitation experience and associated outcomes, both relating to synchronous and asynchronous online environments.

Keywords: Interprofessional education; Online, E-learning; Facilitation, Scoping review 


\section{Introduction}

International health reforms have identified collaborative practice as a key solution to strengthening the future health workforce and ultimately improving health outcomes (e.g. World Health Organization 2010; Institute of Medicine 2015). Evidence continues to demonstrate that effective interprofessional education (IPE) - where two or more professions learn about, from and with each other (World Health Organization 2010) - can equip healthcare learners with the attitudes, knowledge and skills needed to work effectively in collaborative practice (Institute of Medicine 2015; Reeves et al. 2016a). As a result of this expanding evidence base, arguably, IPE is increasingly being offered across the healthcare sector to pre-licensure and post-licensure learners based in numerous countries around the globe (Dow \& Reeves 2017).

IPE has traditionally been delivered in a face-to-face manner to learners based in classrooms and simulation labs, and on placements both in community and clinical settings. In recent years, however, online delivery of IPE has become more prevalent (Curran et al 2015). This increase reflects an acknowledgment that online delivery can overcome a range of complicated scheduling and geographical challenges associated with face-to-face IPE delivery (e.g. Casimiro et al. 2009; Evans et al. 2013; Santy et al. 2009). It also recognises the alignment between the key principles of interprofessional learning and the shift of online learning toward collaborative constructivist approaches that engage groups of learners in discourse and reflection (Bromage et al 2010; Garrison 2017). The increase in online IPE has also coincided with an increase in the use of innovative technologies to facilitate collaboration in the healthcare setting (Reeves \& Freeth 2003).

Over the past decade there has been a growth in studies examining the effects of online IPE. For example, a recent review of 55 papers that used information and communication technologies (ICTs) in the delivery of IPE reported that learners reacted 
favourably to these new methods and experienced positive attitudinal and knowledge changes related to collaborative practice (Curran et al. 2015). While this review provides useful evidence to support the potential effectiveness of the online delivery of IPE for learners, there remains limited attention placed on examining the role of the facilitator in this process.

It is well documented that interprofessional interaction and reflective discourse are essential to any IPE endeavour, a reflection of IPE's grounding in adult learning and constructivist learning theories (Barr et al. 2005). It is therefore not surprising that effectively facilitating this interprofessional interaction and reflective discourse is recognised as crucial to enable interprofessional learning (Hammick et al. 2007; Reeves et al. 2007). The IPE facilitator plays an important role in creating a positive and collaborative learning environment conducive to interprofessional learning (Howkins \& Bray 2008; Reeves et al. 2016a). Their role is to guide and support students through the learning process and provide opportunities to enhance their understanding of what they have learned. The IPE facilitator aims to enable interaction between the learners, encouraging them to share and reflect on their professional perspectives, all while managing the teams' development and dynamics, and the diversity of the group (Solomon \& King 2010; Reeves et al. 2016a).

Over the past few years, a small number of studies have begun to focus on the experiences of, and strategies used, in IPE facilitation (e.g. Lindqvist \& Reeves 2007; van Soeren et al. 2011), however these have mainly focused on facilitation in the face-to-face environment. A recent synthesis of the qualitative evidence of the facilitation of IPE identified only three (out of 12) IPE facilitation studies that were based on an online delivery method (Reeves et al. 2016b). To date, however, there has been no attention on reviewing and synthesising the evidence on the facilitation of online IPE. Given the central importance of the IPE facilitator in guiding the interaction and reflective discourse essential for 
interprofessional learning, combined with the recent growth in online IPE, there is a clear need to better understand the facilitation role and the facilitation experience in online IPE.

\section{Methods}

\section{Aim of review}

The aim of this review was to explore the health professions education literature to understand the extent, range and nature of research on online IPE facilitation. A scoping review methodology was selected, following Arskey and O’Malley’s (2005) framework for this type of interpretive review, with modifications suggested by Levac et al. (2010). See Table 1 for an overview of the different phases.

\section{INSERT TABLE 1 ABOUT HERE}

\section{Step 1: Identify the research question}

The following three research questions guided the scoping review:

1. What aspects of online IPE facilitation have been explored?

2. What do we know about the training, support, roles and experiences of online IPE facilitators?

3. What are the gaps in online IPE facilitation research and what are the key research priorities for the future?

\section{Step 2: Identify relevant studies}

A search strategy aimed to identify any peer-reviewed online IPE facilitation studies published in English until the end of March 2017. Using the research questions as a guide, keywords were identified and preliminarily applied to two electronic databases: Medline and Cumulative Index to Nursing and Allied Health Literature (CINAHL). This preliminary search provided insight into the relevance of the keywords and numerical results generated. 
This preliminary search strategy was then further developed in consultation with an experienced health information scientist including the refinement of keywords, the use of thesaurus terms from databases, the identification of additional databases and the appropriate use of Boolean searching techniques. The final strategy was then applied to the following four main health professions electronic databases: Medline, CINAHL, Education Resources Information Centre (ERIC) and Excerpta Medical Database (EMBASE). Table 2 presents a detailed description of the search strategy as applied to Medline, including both the search terms and Medical Subject Headings (MeSH). Corresponding subject headings/descriptors were, where appropriate, also used in CINAHL, ERIC and EMBASE search strategies.

\section{INSERT TABLE 2 ABOUT HERE}

A hand-search of a leading interprofessional journal of articles published between January 2000 and March 2017 was conducted to identify additional papers that met the inclusion criteria. This journal was selected as it had published the majority of papers found in the searches. In addition, reference lists of the final included articles were reviewed.

\section{Step 3: Study selection}

Studies which evaluated online IPE facilitation were included in this review. For the purposes of this selection, IPE was defined as “any activity that occurs when two or more professions learn about, from and with each other to enable effective collaboration and improve health outcomes” (World Health Organization 2010, p.13). The IPE activities could therefore include pre and/or post licensure learners, and formal and/or non-formal pedagogical approaches. The IPE activities needed to be delivered solely online or as part of a blended learning approach; activities delivered only face-to-face were excluded. Online delivery was defined as the use of any ICTs to implement IPE, such as the internet and web- 
based learning management systems. IPE facilitators were regarded as those individuals (e.g. mentors, teachers) involved in the delivery of IPE to the learners. This did not include individuals responsible for the design and development of the learning experience. All research evaluation designs, either qualitative, quantitative or mixed methods, were included. Papers that did not clearly outline the role of the facilitator, characteristics of the facilitator and details on how data was collected were excluded.

Figure 1 presents the study selection processes. The search strategy identified an initial yield of 2095 potential sources. Following the removal of duplicates, the abstracts and titles of 1582 articles were independently screened by two of the authors to determine if they met the inclusion criteria. This identified 105 papers whose full text were screened for eligibility by the two researchers. Following this rigorous screening process 10 studies were identified for inclusion in this review.

\section{INSERT FIGURE 1 ABOUT HERE}

\section{Step 4: Chart, collate, summarise and report results}

Two of the authors developed a data charting (abstraction) form for extracting key information from the selected studies. These authors then extracted information from the first three included studies, thereafter meeting to ensure their approach was consistent with the research questions, and further refined the data charting form. Information was then extracted from the remaining seven studies. Final data that was extracted from each of the studies included key characteristics (authors, year of publication, journal, study objectives, methodology, and participant details), contextual information (information about the IPE activity, the delivery method, the role of the facilitator, and the training and support provided) and key findings in relation to online IPE facilitation. To identify key themes of the studies, the extracted data was analysed using Braun and Clarke’s (2006) approach to thematic analysis. 


\section{Results}

\section{Overview of studies}

Table 3 provides an overview of the characteristics of the 10 included studies. Of these studies, three were undertaken in Canada, three in Australia (by the same research group), two in the United States of America and one each in the United Kingdom and Finland. In all but one of these studies, the role of the facilitator included facilitating teams of students on asynchronous discussion boards in dialogue which was either case-based or focused on unique aspects of collaborative practice. Three of the papers (Evans et al. 2014; 2016; 2017) also included a role in facilitating synchronous activities, while one study (Hanna et al. 2013) involved facilitating in only the synchronous medium. All studies used a single facilitation approach apart from Hanna et al. (2013) who used co-facilitation in the synchronous medium. Most studies used health professionals or faculty members in the facilitation role, however two utilized students/peers in this role (Clouder et al. 2012; Kroph et al. 2015). All but one of the studies involved facilitators working on IPE activities with pre-licensure students from between three and 11 different professions. Hanna et al. (2013) however, involved postlicensure learners undertaking continuing professional development. Training prior to undertaking the online IPE facilitating role was only briefly alluded to in six of the studies (Becker \& Goodwin 2005; Clouder et al 2012; Evans et al 2017; Hanna et al 2013; Kroph et al 2015; Solomon \& King 2010) and was not mentioned at all in the other four studies (Evans et al 2014; Evans et al 2016; Juntunen \& Heikkinen 2004; Waterston 2001). Similarly, support while undertaking the role was briefly highlighted in only five of the studies (Becker \& Goodwin 2005; Clouder et al 2012; Evans et al 2014; Hanna et al 2013; Kroph et al 2015). A variety of methods were used to collect study data. Analysis of online facilitation contributions (five studies) and individual interviews (five studies) were most commonly used. As part of mixed methodological approaches in the studies, a number of other methods 
were used such as a focus group (one study), online evaluation form (one study), assessment of contributions by e-learning expert and review of other written documentation such as written reflections (one study), weekly debriefing documentation (one study) and application data (one study).

\section{INSERT TABLE 3 ABOUT HERE}

\section{Key themes}

Based on the thematic analysis outlined above, three key themes emerged from the included studies: types of online IPE facilitation contributions, the experience of online IPE facilitating, and personal outcomes of online IPE facilitation.

\section{Types of online IPE facilitation contributions}

The most common focus of the included papers was on the facilitators' contributions to online asynchronous team discussions (Becker \& Godwin 2005; Evans et al. 2017; Juntunun \& Heikkinen 2004; Kroph et al. 2015; Solomon \& King 2010; Waterston 2011). The facilitators' contributions were described in various ways. In some cases they were supported by a range of frameworks or models, such as the Community of Inquiry (COI) Framework (Evans et al. 2017; Waterston 2011), or Cooperative Learning (Waterston 2011). In other cases, the authors labelled their own descriptors of the contributions, such as “professional expertise” (Becker \& Godwin 2005, p 173) and “making the links” (Solomon \& King 2010, p 52). In one case, the authors clustered the contributions into three major types: “amplifying statements”, “augmenting posts” and “analysing comments” (Kroph et al. 2015, p 377).

Regardless of whether they were underpinned by a model or by their own descriptions, a range of contributions were noted across the studies. One of the most common of these was 
aimed at instigating discussion among learners. A number of techniques were used to instigate this discussion such as:

- Encouraging, acknowledging and/or reinforcing past student input (Becker \& Godwin 2005; Evans et al. 2017; Waterston 2011)

- Encouraging students to participate (Evans et al. 2017; Waterston 2011)

- Highlighting similar experiences (Kroph et al. 2015)

- Adding depth to feedback (Kroph et al. 2015).

Some authors were able to group these specific techniques into broader categories, labelled as “facilitating discourse” (Evans et al. 2017, p 776; Waterston 2012, p 276), or “amplifying [student] posts” (Kroph et al. 2015, p 377). Conversely, Juntunun and Heikkinen (2004) reported that their facilitators rarely tried to motivate the students and summarised that teachers need to develop their teaching skills to facilitate web-based learning.

Another common type of contribution made by facilitators was adding knowledge or content to the discussion. Specific methods to add this knowledge/content included:

- Providing professional expertise/content or reflections on their own experiences (Becker \& Godwin 2005; Evans et al. 2017; Kroph et al. 2015; Waterston 2011)

- Presenting specific questions for consideration and to promote reflection (Becker \& Godwin 2005; Evans et al. 2017; Kroph et al. 2015; Solomon \& King 2010; Waterston 2011)

- Summarising the content (Evans et al. 2017; Solomon \& King 2010) with a particular focus on modelling interprofessional work (Solomon \& King 2010). 
Again, these specific techniques were able to be grouped into broader categories by some authors, being collectively labelled as “augmenting posts” (Kroph et al. 2015, p 378) or “direct instruction” (Evans et al. 2017, p 776; Waterston 2011, p 276). As well as trying to instigate further discussion and adding knowledge/content, the facilitators in some studies also frequently reminded students about learning activities and assessment, and provided feedback (Evans et al. 2017; Becker \& Godwin 2005).

The content of the facilitators' contributions and the timing of these contributions were linked to learners' participation and perceptions of the experience in two of the studies. The first, Becker and Godwin (2005), found that messages from facilitators that restated assignments, provided technical information and provided reinforcement correlated with increased numbers of student messages. The second, by Waterston (2011), reported that when it was optional for facilitators to participate in the online discussions, it was more likely that the learners perceived positive value in the discussions when the facilitator did participate. In the positive teams, facilitators set an example by posting by the first day whereas in the one negative team with facilitator involvement the facilitator did not post until halfway through the curriculum.

\section{The experience of online IPE facilitating}

While the type of contributions was by far the most popular theme of the included studies, a number of papers explored what it was like to facilitate in the online IPE environment (Evans et al. 2014; Hanna et al. 2013). In reflecting on the facilitators' experiences in both asynchronous and synchronous facilitation, Evans et al. (2014) for example found the facilitating experience to be positive due to factors such as "perceiving the students were learning”, "the flexibility of the role” and "feeling supported as a facilitator" (p 
1053). As many of the facilitators were fitting the facilitating in around other aspects of their lives, these positive aspects of the experience were particularly noteworthy.

Challenges of the facilitating experience were also highlighted. While difficulties engaging some students in the asynchronous environment was noted (Evans et al. 2014), most of the challenges related to synchronous facilitation, particularly managing technological problems/challenges (Evans et al. 2014; Hanna et al. 2013). The technological problems included log-on issues, being disconnected during the sessions, and malfunctioning headsets/microphones during the sessions (Evans et al. 2014). It was suggested that this resulted in the need for the facilitator to manage not only the professional hierarchies that can be experienced in IPE but also a hierarchy defined by how skilfully the participants dealt with the technology challenges (Hanna et al. 2013). At times, it was reported that technology challenges were able to be turned in to "learning experiences" (Evans et al. 2014, p 1054) or “teachable moments” (Hanna et al. 2013, p 302) by the facilitators for the students. Further, troubleshooting training, having a contingency plan and prioritizing collaboration among learners ahead of seeking technological perfection were all helpful in this process (Hanna et al. 2013).

The experience of facilitation in the synchronous environment was also made challenging by the reduction in non-verbal cues (Evans et al. 2014; Hanna et al. 2013) and the slower development of group processes (Hanna et al. 2013). Facilitators in the synchronous environment did identify the importance of co-facilitation to address content and process gaps, to model interprofessional collaboration with their partner, and to learn about facilitation in that environment (Hanna et al. 2013).

\section{Personal outcomes of online IPE facilitation}


The third theme of the included papers related to outcomes of the facilitating experience for the facilitators themselves. These outcomes were of a personal nature rather than specific to the learners engaged in the online IPE activities. The most common of these outcomes was the facilitators experiencing their own interprofessional learning as a result of their facilitation role. Both peer facilitators (Clouder et. 2012) and health professional facilitators (Evans et al. 2016) reported increasing their own understanding of other professions as a result of the facilitation experience. For example, Evans et al. (2016) noted "the unit refreshed or refined their knowledge of the roles of different health professionals, and in turn resulted in a greater sense of appreciation for the various contributors to a healthcare team” (p 704). These authors also reported facilitators gaining an improved theoretical and empirical understanding of collaborative practice following their involvement. In addition to interprofessional learning, peer facilitators also reported other personal growth such as having developed skills in reflection, organization, communication, teaching/facilitation, diplomacy, conflict resolution and overall a greater sense of confidence, along with the opportunity for interprofessional identify development (Clouder et al. 2012). Similarly, the development of their own skills as both an IPE facilitator and an online facilitator was reported as an outcome of being involved in the facilitation (Evans et al. 2014).

Evans et al. (2016) also reported facilitators having changed several professional behaviours as a result of their facilitation role. This included improved interprofessional collaboration with colleagues, a more explicit focus on interprofessional care planning, and changes to their student and staff supervision practices to greater reflect principles of collaborative practice.

\section{Discussion}


The aim of this scoping review was to explore the health professions education literature to understand the extent, range and nature of research on online IPE facilitation. While accounts of online IPE are increasingly reported in the literature (e.g. Curran et al. 2015), this review identified only 10 studies that discussed online IPE facilitation in some depth. These studies provide some insights into a range of aspects of online IPE facilitation, however this limited number clearly highlights the need for further exploration of this expanding area of health professions education.

As presented above, the studies included in this review covered a range of aspects related to online IPE facilitation. A key focus was related to the types of contributions the facilitators made in guiding learners on an asynchronous basis using discussion boards (five of the ten included studies). This is not surprising given asynchronous discussion boards are the most commonly used ICT to deliver IPE (Curran et al. 2015) and that a facilitator's presence is critical in creating and maintaining a dynamic collaborative online learning environment (Garrison 2017). The review found that the online IPE facilitators made a variety of contributions to their team discussion to instigate further dialogue among learners, to add knowledge or provide instruction. These types of contributions map closely with a number of empirically supported classification schemes of key online teaching roles which highlight the need for facilitating discourse, providing intellectual or direct instruction, and providing organisational design (e.g. Anderson et al. 2001; Berge 1995; Paulsen 1995). Given the important role of the IPE facilitator in encouraging students to share their professional perspectives (Solomon \& King 2010) to enable them to learn interactively, the use of these methods, in particular those focused on instigating further discussion among learners, were critical.

Only two of these five studies which considered the online IPE facilitators contributions reported on the impact of these contributions on learners' participation and 
perceptions of the experience (Becker \& Godwin 2005; Waterston 2011). Both of these studies suggest that involvement from facilitators may result in a more positive experience for the learners and greater learner participation. These findings accord well with the broader online learning literature which has consistently reported the importance of teaching presence for perceived learning and satisfaction (e.g. Akyol \& Garrison 2010; Yang et al. 2016). Unlike the broader online learning literature however, none of the studies in this review explored how the types of contributions made by the online IPE facilitators varied over the duration of the course, nor the relationship between the online IPE facilitators' contributions and the learners academic performance and attainment of intended learning outcomes (e.g. Szeto 2015; Vaughan \& Garrison 2006; Yang et al. 2016). Similarly, it is not clear from the included studies how the facilitators' contributions may vary between different types of online asynchronous discussion activities (e.g. case based discussion versus dialogue about a specific collaborative practice issue). Additionally, the studies included in the review did not explore the online IPE facilitators' contributions from a social presence perspective. Social presence focuses on the creation of a social-emotional climate for rich open communication that can build cohesion for sustained collaborative inquiry and is particularly challenging to develop in text-based communication (Garrison 2017).

While the types of contributions made by the facilitators was clearly the most prevalent theme in the included studies, two other important themes were also noted in the review. Firstly, a number of papers described the "experience” of facilitation in the asynchronous and synchronous environments (Evans et al. 2014; Hanna et al. 2013). This experience was typified by positive factors but also highlighted challenges of facilitation, particularly in the synchronous environment. Both positive factors and challenges have similarly been reported as part of the student's online IPE experience (Curran et al. 2015) and for facilitators in other online learning environments (e.g. Cornelius 2014). A number of the 
studies also reported results relating to outcomes associated with IPE facilitation. Two papers reported the acquisition of knowledge by the online IPE facilitators, reporting their own interprofessional learning associated with their role (Clouder et al. 2015; Evans et al. 2016). This finding resonates well with the concept that, in any educational experience, thinking and learning should be shared, and that teachers are learners and learners are teachers (Garrison 2017). The facilitators’ own interprofessional learning therefore is likely to reflect the opportunity provided by the facilitation role to engage in thoughtful discourse and reflection with their community of learners. Further, one of the included studies reported that facilitators were successful in transferring some of their own collaborative learning during their online experiences to behaviour change in their own practice settings (Evans et al. 2016).

While these limited number of studies provide some insight into online IPE facilitation, it is clear that there are a number of gaps in the online IPE facilitation research necessitating further inquiry in this area. As already outlined, the studies in this review demonstrate that we have some understanding of the contributions online IPE facilitators make on asynchronous team discussion boards, however, more extensive research is required to explore the range of contributions which may exist, how these may vary over time in the course, and how they may or may not differ between different types of discussion activities This further exploration of online IPE facilitator asynchronous discussion contributions needs to not only explore the teaching presence contributions, but also those that assist with contributing to the sense of identity and collaboration of the group (i.e. social presence). Importantly, an understanding of the influence of all of these variations of online IPE facilitators asynchronous contributions on the learners' experience, their interactivity and discourse, and ultimately their interprofessional learning and outcomes is needed. This insight would enable those designing online IPE experiences in the future to optimise the teaching and learning experiences for both facilitators and learners. 
None of the studies in this review explored what contributions facilitators were actually making in the synchronous environment. Given synchronous delivery methods, such as video-conferencing, are commonly used in IPE (Curran et al. 2015), further research should explore what facilitation strategies the facilitators are actually using in this medium. The facilitation strategies in the synchronous environment may have similarities to face-toface IPE facilitation, and/or asynchronous discussion board facilitation, but given the challenges of technology acknowledged in the two papers that discussed synchronous delivery in detail (Evans et al. 2014; Hanna et al. 2013) and in the broader online teaching and learning literature (e.g. Cornelius 2014), it is probable that there may be some differences in the strategies used. These potential nuances of synchronous IPE facilitation need to be examined and understood.

More qualitative inquiry is also required to better understand individual outcomes associated with online IPE facilitation in relation to the facilitators own experience, modification of their attitudes, acquisition of knowledge, and behaviour change. An understanding of the interprofessional learning the facilitators themselves glean from their community of learners may be useful in the future recruitment of facilitators and to advocate for a dual purpose in facilitation.

Finally, future research needs to explore the training and support required for online IPE facilitators. While approximately half of the studies in this review made reference to training and/or support for the online facilitators, none provided any significant details of these. While there is emerging literature on the importance and contents of training for IPE facilitators (e.g. LeGros et al. 2015; Milot et al. 2017), along with a well-established body of literature focusing on training for online teaching in general (e.g. Hampel \& Stickler 2005; Gold 2001), we currently have no detailed insight into the specific training and support 
requirements of online IPE facilitation. Given the critical role of the online IPE facilitator, the importance of adequate training and support cannot be understated.

A particular methodological strength of some of the studies in this review is that they gathered data on the facilitators' practices - their actual online teaching contributions/interactions with learners (Becker \& Godwin 2005; Evans et al. 2017; Kroph et al. 2015; Waterston 2011) - rather than self-report data which would provide only a perception of practice. As such, these studies offer a preliminary robust insight into the actual nature of IPE facilitators' online actions.

Nevertheless, like all scoping reviews, there are a number of limitations with this work. For example, the search was limited by including studies only published in English and by excluding the grey literature. Also, the search only used four databases and undertook a hand search of only one journal. As a result of these limitations, it is possible that a small number of relevant studies may have been overlooked.

\section{Conclusion}

This review has highlighted that while studies of online IPE are emerging in the literature, there is still minimal research examining the nature of facilitation of online IPE. The ten studies included in this review provide some understanding of the contributions facilitators make in asynchronous IPE facilitation, and the outcomes associated with the online facilitation experience. It is clear, however, that more extensive research is needed to increase our understanding of the range of contributions the facilitators make in both synchronous and asynchronous environments, and how these relate to the students learning experience and actual interprofessional learning, along with further exploration of the training and support requirements of online IPE facilitation. This knowledge would enable us to better 
tailor recruitment and training of future facilitators, provide appropriate support during facilitation periods, and ultimately improve the learning environment for the learners.

\section{References}

Anderson T, Rourke L, Garrison R, Archer W. 2001. Assessing teaching presence in a computer conferencing context. J Asynch Learn Networks, 5:1-17.

Arksey H, O’Malley L. 2005. Scoping studies: Towards a methodological framework. Int J Soc Res Methodol. 8:19-32.

Aykol Z, Garrison D. 2010. Learning and satisfaction in online communities of inquiry. In: Eom S \& Arbaugh J, editor. Student satisfaction and learning outcomes in elearning: an introduction to empirical research. Hershery (AP): IGI Global; p 23-35.

Barr H, Koppel I, Reeves S, Hammick M, Freeth D. 2005. Effective interprofessional education: argument, assumption and evidence. Oxford (UK): Blackwell Publishing.

Becker N, Godwin N. 2005. Methods to improve teaching interdisciplinary teamwork through computer conferencing. J Allied Health, 34:169-176.

Berge Z. 1995. Facilitating computer conferencing: recommendations from the field. Educ Tech. 15:22-30

Braun C, Clarke V. 2006. Using thematic analysis in psychology. Qual Res Psych. 3: 77-101.

Bromage A, Clouder L, Thistlethwaite J, Gordon F. 2010. Interprofessional e-learning and collaborative work: practices and technologies. New York (US): Information Science Reference.

Casimiro L, MacDonald C, Thompson T, Stodel E. 2009. Grounding theories of W(e) Learn: A framework for online interprofessional education. J Interprof Care. 23:390-400.

Clouder D, Davies B, Sams M, McFarland L. 2012. “Understanding where you're coming from'”: discovering an [inter]professional identity through becoming a peer facilitator. J Interprof Care. 26:459-464.

Cornelius S. 2014. Facilitating in a demanding environment: experiences of teaching in virtual classrooms using web conferencing. Br J Educ Technol. 45:260-271.

Curran V, Reid A, Reis P, Doucet S, Price S, Alcock L, Fitzgerald S. 2015. The use of information and communications technologies in the delivery of interprofessional education: a review of evaluation outcomes levels. J Interprof Care. 29:541-550.

Dow A, Reeves S. 2017. How health professional training will and should change. In T Hoff, K Sutcliffe, G Young (Eds.) The Healthcare Professional Workforce: Understanding Human Capital in a Changing Industry. Oxford (UK): Oxford University Press. 
Evans S, Sønderland A, Tooley G. 2013. Effectiveness of online interprofessional education in improving students' attitudes and knowledge associated with interprofessional practice. Focus Health Prof Educ. 14:12-20.

Evans S, Knight T, Sønderlund A, Tooley G. 2014. Facilitators’ experience of delivering asynchronous and synchronous online interprofessional education. Med Teacher. 36:1051-1056.

Evans S, Shaw N, Ward C, Hayley A. 2016. Refreshed... reinforced...reflective: a qualitative exploration of interprofessional education facilitators' own interprofessional learning and collaborative practice. J Interprof Care. 30:702-709.

Evans S, Ward C, Reeves S. 2017. An exploration of teaching presence in online interprofessional education facilitation. Med Teacher. 39:773-779.

Freeth D, Hammick M, Reeves S, Koppel I, Barr H. 2005. Effective interprofessional education: development, delivery and evaluation. Oxford (UK): Blackwell Publishing.

Garrison R. 2017 E-learning in the $21^{\text {st }}$ century: a community of inquiry framework for research and practice. New York (US): Routledge.

Gold S. 2001. A constructivist approach to online training for online teachers. J Asynch Learn Networks. 5: 35-57.

Hammick M, Freeth D, Koppel I, Reeves S, Barr H. 2007. A best evidence systematic review of interprofessional education. Med Teacher. 29:735-51.

Hampel R, Stickler U. (2005). New skills for new classrooms: training tutors to teach languages online. Comp Assist Lang Learn. 18:311-326.

Hanna E, Soren B, Telner D, MacNeill H, Lowe M, Reeves S. 2013. Flying blind: the experience of online interprofessional facilitation. J Interprof Care. 27:298-304.

Howkins E, Bray J. 2008. Through the PIPE. In: Howkins E, Bray J, editors. Preparing for interprofessional teaching: theory and practice. Oxford (UK): Radcliffe Publishing.

Institute of Medicine. 2015. Measuring the impact of interprofessional education on collaborative practice and patient outcomes. Washington, DC: National Academy of Sciences.

Juntunen A, Heikkinen A. Lessons from interprofessional elearning: piloting a care of the elderly module. J Interprof Care. 18:269-278.

Kropf N, Idler E, Flacker J, Clevenger C, Rothschild E. 2015. Interprofessional Dialogues Within a Senior Mentoring Program: Incorporating Gerontology Students as Facilitation Leaders. Educational Gerontology. 41:373-383.

LeGros T, Amerongen H, Colley J, Schloss E. 2015. Using learning theory, interprofessional facilitation competencies, and behaviour indicators to evaluate facilitator training. J Interprof Care. 29:596-602. 
Levac D, Colquhoun H, O’Brien K. 2010. Scoping studies: advancing the methodology. Implement Sci. 5:69.

Lindqvist S, Reeves S. 2007. Facilitators' perceptions of delivering interprofessional education: a qualitative study. Med Teach. 29:403-405.

Milot E, Museux A, Careau E. 2017. Facilitator training program: the université laval interprofessional initiative. Soc Work Health Care. 56:202-214.

Paulsen M. 1995. Moderating education computer conferences. In: Berge Z \& Collins M, editor. Computer medicated communication and the online classroom. Cresskill (US): Hamptom Press Inc; p. 81-90.

Reeves S, Fletcher S, Barr H, Birch I, Boet S, Davies N, Kitto S. 2016a. A BEME systematic review of the effects of interprofessional education: BEME Guide No. 39. Med Teach. 38:656-668.

Reeves S, Freeth D. 2003. New forms of information technology, new forms of collaboration? In A Leathard (Ed) Interprofessional Collaboration: From Policy to Practice in Health and Social Care. London. (UK): Routledge.

Reeves S, Goldman J, Oandasan I. 2007. Key factors in planning and implementing interprofessional education in health care settings. J Allied Health, 36: 231-235.

Reeves S, Pelone F, Hendry J, Lock N, Marshall J, Pillay L, Wood R. 2016b. Using a meta-ethnographic approach to explore the nature of facilitation and teaching approaches employed in interprofessional education. Med Teach. 38:1221-1228.

Santy J, Beadle M, Needham Y. 2009. Using an online case conference to facilitate interprofessional learning. Nurse Ed Prac, 9:383-387.

Solomon P, King S. 2010. Online interprofessional education: perceptions of faculty facilitators. J Phys Ther Educ. 24:51-53.

Szeto E. 2015. Community of inquiry as an instructional approach: what effects of teaching, social and cognitive presences are there in blended synchronous learning and teaching? Comput Educ. 81:191-201.

van Soeren M, Devlin-Cop S, MacMillan K, Baker L, Egan-Lee E, Reeves S. 2011. Simulated interprofessional education: an analysis of teaching and learning processes. J Interprof Care. 25:434-440.

Waterston R. 2011. Interaction in online interprofessional education case discussions. J Interprof Care. 25:272-279.

World Health Organization. 2010. Framework for action on interprofessional education and collaborative practice. Geneva: Author.

Yang J, Quadir B, Chen B, Miao Q. 2016. Effects of online presence on learning performance in a blog-based online course. Internet High Educ. 30:11-20. 


\section{Practice Points}

- The use of online media to deliver IPE is becoming more prevalent.

- While it is known that the facilitator is critical to the success of IPE endeavours, we have a limited understanding of facilitation in the online IPE environment.

- This scoping review found that a small amount of research has examined the types of online IPE facilitation contributions, the experience of online facilitation and the personal outcomes of IPE facilitation.

- More extensive research is needed to further increase our understanding of online IPE facilitation.

\section{Declaration of Interest}

The authors report no conflict of interest.

\section{Notes on contributors}

Sherryn Evans, M Diet, is a Senior Lecturer and the Interprofessional Education Coordinator in the Faculty of Health, Deakin University, Australia.

Catherine Ward, B App Sc OT, is a Lecturer in Interprofessional Education in the Faculty of Health, Deakin University, Australia.

Scott Reeves, PhD, is Professor in Interprofessional Research at the Centre for Health and Social Care Research, Kingston University and St George’s, University of London, UK. 
Table 1: Overview of the framework for conducting a scoping study

\begin{tabular}{|c|c|}
\hline Review Stage & Description \\
\hline $\begin{array}{l}\text { 1: Identifying the } \\
\text { research question }\end{array}$ & $\begin{array}{l}\text { Identifying the research question provides the roadmap for subsequent } \\
\text { stages. Relevant aspects of the question must be clearly defined as they } \\
\text { have ramifications for search strategies. Research questions are broad in } \\
\text { nature as they seek to provide breadth of coverage. }\end{array}$ \\
\hline $\begin{array}{l}\text { : Identifying } \\
\text { relevant studies }\end{array}$ & $\begin{array}{l}\text { This stage involves identifying the relevant studies and developing a } \\
\text { decision plan for where to search, which terms to use, which sources are to } \\
\text { be searched, time span, and language. Comprehensiveness and breadth is } \\
\text { important in the search. Sources include electronic databases, reference } \\
\text { lists, hand-searching of key journals, and organizations and conferences. } \\
\text { Breadth is important; however, practicalities of the search are as well. } \\
\text { Time, budget and personal resources are potential limiting factors and } \\
\text { decisions need to be made upfront about how these will impact the search. }\end{array}$ \\
\hline 3: Study selection & $\begin{array}{l}\text { Study selection involves post hoc inclusion and exclusion criteria. These } \\
\text { criteria are based on the specifics of the research question and on new } \\
\text { familiarity with the subject matter through reading the studies. }\end{array}$ \\
\hline 4: Charting the data & $\begin{array}{l}\text { A data-charting form is developed and used to extract data from each study. } \\
\text { A 'narrative review' or 'descriptive analytical' method is used to extract } \\
\text { contextual or process oriented information from each study. }\end{array}$ \\
\hline $\begin{array}{l}\text { 5: Collating, } \\
\text { summarizing, and } \\
\text { reporting results }\end{array}$ & $\begin{array}{l}\text { An analytical framework or thematic construction is used to provide an } \\
\text { overview of the breadth of the literature but not a synthesis. A numerical } \\
\text { analysis of the extent and nature of studies using tables and/or charts is } \\
\text { presented. A thematic analysis is then presented. Clarity and consistency } \\
\text { are required when reporting results. }\end{array}$ \\
\hline $\begin{array}{l}\text { 6: Consultation } \\
\text { (optional) }\end{array}$ & $\begin{array}{l}\text { Provides opportunities for consumer and stakeholder involvement to } \\
\text { suggest additional references and provide insights beyond those in the } \\
\text { literature. }\end{array}$ \\
\hline
\end{tabular}


Table 2. Medline Search Strategy

\begin{tabular}{|l|l|}
\hline Step & Search terms \\
\hline 1 & $\begin{array}{l}\text { "Inter*professional education” OR “inter*professional learning” OR IPE OR } \\
\text { "inter*disciplinary education” OR “inter*disciplinary learning” OR } \\
\text { "multi*disciplinary education” OR “multi*disciplinary learning” OR } \\
\text { "multi*professional education” OR “multi*professional learning” }\end{array}$ \\
\hline 2 & $\begin{array}{l}\text { Online OR “electronic learning” OR e*learning OR “technology*enhanced learning” } \\
\text { OR “blended learning” OR "remote learning” }\end{array}$ \\
\hline 3 & "Internet” [MeSH] OR “educational technology” [MeSH] \\
\hline 4 & S2 or S3 \\
\hline 5 & Facilitat* OR teach* OR tutor* OR lectur* OR supervis* \\
\hline 6 & S1 AND S4 and S5 \\
\hline 7 & And Filters: English \\
\hline
\end{tabular}




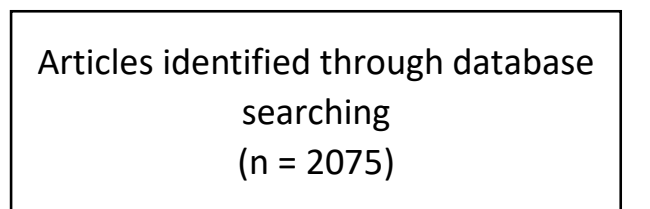
searching $(n=2075)$
Additional articles identified through other sources

$$
(n=20)
$$
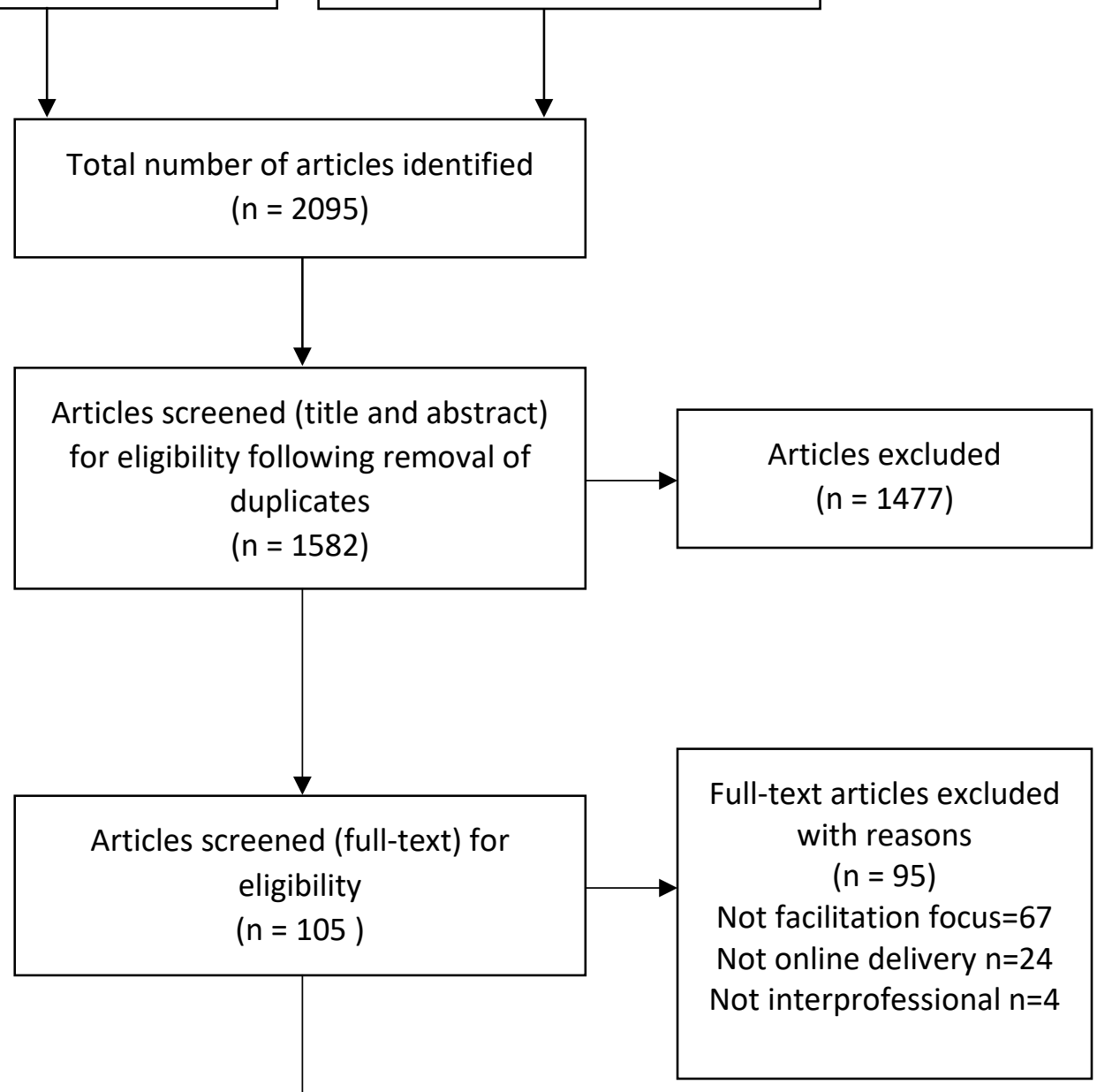

Studies included in final review

$$
(n=10)
$$

Figure 1: Searching and Screening Results 
Table 3. Overview of facilitation research

\begin{tabular}{|c|c|c|c|c|c|c|c|}
\hline Citation & Country & Purpose of study & $\begin{array}{l}\text { Description of IPE } \\
\text { activity }\end{array}$ & $\begin{array}{l}\text { Learners involved in } \\
\text { the IPE activity }\end{array}$ & $\begin{array}{c}\text { Facilitator role in IPE } \\
\text { activity }\end{array}$ & $\begin{array}{l}\text { Facilitator Training } \\
\text { and Support }\end{array}$ & $\begin{array}{l}\text { Reported Facilitator } \\
\text { Characteristics }\end{array}$ \\
\hline $\begin{array}{l}\text { Becker \& } \\
\text { Godwin } \\
2005\end{array}$ & USA & $\begin{array}{l}\text { To explore “... whether } \\
\text { orienting students to } \\
\text { their virtual classroom } \\
\text { and coaching faculty to } \\
\text { increase student } \\
\text { interaction would } \\
\text { improve teaching in a } \\
\text { 6-week } \\
\text { interdisciplinary } \\
\text { module” (p. 170) }\end{array}$ & $\begin{array}{l}\text { Asynchronous } \\
\text { discussions based on } \\
\text { case studies over a } 6 \\
\text { week period }\end{array}$ & $\begin{array}{l}\text { First year pre-licensure } \\
\text { from three professions } \\
\text { Professions } \\
\text { represented: } \\
\text { Occupational Therapy, } \\
\text { Physical Therapy and } \\
\text { Respiratory Care }\end{array}$ & $\begin{array}{l}\text { Facilitating teams of 4- } \\
6 \text { students in online } \\
\text { asynchronous } \\
\text { discussions }\end{array}$ & $\begin{array}{l}\text { WebCT courseware } \\
\text { training } \\
\text { Support via weekly } \\
\text { feedback from module } \\
\text { coordinators on } \\
\text { methods to improve } \\
\text { interaction }\end{array}$ & $\begin{array}{l}11 \text { facilitators. } 6 \text { in an } \\
\text { experimental group } \\
\text { who were given weekly } \\
\text { feedback on methods to } \\
\text { enhance discussions } \\
\text { within their student } \\
\text { teams. } 5 \text { facilitators } \\
\text { acted as a control group } \\
\text { Profession not } \\
\text { specified }\end{array}$ \\
\hline $\begin{array}{l}\text { Clouder et } \\
\text { al. } 2012\end{array}$ & UK & $\begin{array}{l}\text { "To explore: (1) the } \\
\text { range } \\
\text { of cognitive, personal } \\
\text { and instrumental gains } \\
\text { for peer } \\
\text { facilitators in the online } \\
\text { IPLP and" } \\
\text { (p. } 461 \text { ) }\end{array}$ & $\begin{array}{l}\text { Asynchronous } \\
\text { discussions based on } \\
\text { scenarios and activities } \\
\text { over a } 4 \text { week period }\end{array}$ & $\begin{array}{l}\text { First year pre-licensure } \\
\text { students from } 14 \\
\text { professions } \\
\text { Professions not } \\
\text { specified }\end{array}$ & $\begin{array}{l}\text { Facilitating teams of } 15 \\
\text { students in online } \\
\text { asynchronous } \\
\text { discussions }\end{array}$ & $\begin{array}{l}\text { Online training } \\
\text { program } \\
\text { Support via online } \\
\text { forum for sharing } \\
\text { experiences along with } \\
\text { access to a learning } \\
\text { technologist, a } \\
\text { coordinator and a } \\
\text { "buddy” academic }\end{array}$ & $\begin{array}{l}41 \text { peer facilitators over } \\
\text { a three year period } \\
\text { from } 7 \text { different } \\
\text { professions } \\
\text { Professions } \\
\text { represented: Dietetics, } \\
\text { Medicine, Midwifery, } \\
\text { Nursing Physiotherapy, } \\
\text { Social Work and Youth } \\
\text { Work }\end{array}$ \\
\hline $\begin{array}{l}\text { Evans et } \\
\text { al. } 2014\end{array}$ & Australia & $\begin{array}{l}\text { “To explore the } \\
\text { facilitators' experience } \\
\text { of online asynchronous } \\
\text { and synchronous IPE } \\
\text { facilitation of pre- } \\
\text { licensure students” (p. } \\
\text { 1052) }\end{array}$ & $\begin{array}{l}\text { Asynchronous } \\
\text { discussions based on } \\
\text { collaborative practice } \\
\text { issues and case studies } \\
\text { over a } 12 \text { week period } \\
\text { along with four } \\
\text { synchronous case } \\
\text { conferences }\end{array}$ & $\begin{array}{l}\text { Pre-licensure students } \\
\text { from } 7 \text { professions } \\
\text { Professions } \\
\text { represented: Clinical } \\
\text { Exercise Physiology, } \\
\text { Dietetics, Medicine, } \\
\text { Nursing, Occupational } \\
\text { Therapy, Psychology, } \\
\text { Social Work }\end{array}$ & $\begin{array}{l}\text { Facilitating teams of } 8 \\
\text { students in } \\
\text { asynchronous } \\
\text { discussions and in } \\
\text { synchronous case } \\
\text { conferences }\end{array}$ & $\begin{array}{l}\text { No training detail } \\
\text { provided } \\
\text { Support via access to } \\
\text { other facilitators and } \\
\text { coordinator via online } \\
\text { discussion boards. }\end{array}$ & $\begin{array}{l}19 \text { facilitators } \\
\text { Professions } \\
\text { represented: Dietetics, } \\
\text { Medicine, Nursing, } \\
\text { Physiotherapy, } \\
\text { Occupational Therapy, } \\
\text { Social Work and } \\
\text { Speech Pathology }\end{array}$ \\
\hline $\begin{array}{l}\text { Evans et } \\
\text { al. } 2016\end{array}$ & Australia & $\begin{array}{l}\text { "To explore the } \\
\text { influence }\end{array}$ & $\begin{array}{l}\text { Asynchronous } \\
\text { discussions based on }\end{array}$ & $\begin{array}{l}\text { Pre-licensure students } \\
\text { from } 7 \text { professions }\end{array}$ & $\begin{array}{l}\text { Facilitating teams of } 8 \\
\text { students in }\end{array}$ & $\begin{array}{l}\text { No training detail } \\
\text { provided }\end{array}$ & 16 facilitators \\
\hline
\end{tabular}




\begin{tabular}{|c|c|c|c|c|c|c|c|}
\hline & & $\begin{array}{l}\text { that facilitating IPE has } \\
\text { on facilitators' own } \\
\text { collaborative } \\
\text { practice attitudes, } \\
\text { knowledge, and } \\
\text { workplace behaviours” } \\
\text { (p. 703) }\end{array}$ & $\begin{array}{l}\text { collaborative practice } \\
\text { issues and case studies } \\
\text { over a } 12 \text { week period } \\
\text { along with four } \\
\text { synchronous case } \\
\text { conferences }\end{array}$ & $\begin{array}{l}\text { Professions } \\
\text { represented: Clinical } \\
\text { Exercise Physiology, } \\
\text { Dietetics, Medicine, } \\
\text { Nursing, Occupational } \\
\text { Therapy, Psychology, } \\
\text { Social Work }\end{array}$ & $\begin{array}{l}\text { asynchronous } \\
\text { discussions and in } \\
\text { synchronous case } \\
\text { conferences }\end{array}$ & $\begin{array}{l}\text { No support detail } \\
\text { provided }\end{array}$ & $\begin{array}{l}\text { Professions } \\
\text { represented: Dietetics, } \\
\text { Nursing, } \\
\text { Physiotherapy, } \\
\text { Occupational Therapy, } \\
\text { Social Work and } \\
\text { Speech Pathology }\end{array}$ \\
\hline $\begin{array}{l}\text { Evans et } \\
\text { al. } 2017\end{array}$ & Australia & $\begin{array}{l}\text { "To explore the } \\
\text { types of contributions } \\
\text { made by IPE } \\
\text { facilitators to } \\
\text { asynchronous } \\
\text { interprofessional team } \\
\text { discussions by using } \\
\text { Anderson et al. (2001) } \\
\text { notion of teaching } \\
\text { presence" (p. } 774)\end{array}$ & $\begin{array}{l}\text { Asynchronous } \\
\text { discussions based on } \\
\text { collaborative practice } \\
\text { issues and case studies } \\
\text { over an } 11 \text { week period } \\
\text { along with four } \\
\text { synchronous case } \\
\text { conferences }\end{array}$ & $\begin{array}{l}\text { Pre-licensure students } \\
\text { from } 7 \text { professions } \\
\text { Professions } \\
\text { represented: Clinical } \\
\text { Exercise Physiology, } \\
\text { Dietetics, Medicine, } \\
\text { Nursing, Occupational } \\
\text { Therapy, Psychology, } \\
\text { Social Work }\end{array}$ & $\begin{array}{l}\text { Facilitating teams of } 8 \\
\text { students in } \\
\text { asynchronous } \\
\text { discussions and the } \\
\text { synchronous case } \\
\text { conferences }\end{array}$ & $\begin{array}{l}\text { Online training that } \\
\text { addressed the content } \\
\text { of the unit, the use of } \\
\text { the various programs, } \\
\text { and their role as a } \\
\text { facilitator of learning } \\
\text { No support detail } \\
\text { provided }\end{array}$ & $\begin{array}{l}28 \text { facilitators } \\
\text { Professions } \\
\text { represented: Dietetics, } \\
\text { Nursing, } \\
\text { Physiotherapy, } \\
\text { Psychology, } \\
\text { Occupational Therapy, } \\
\text { Social Work and } \\
\text { Speech Pathology }\end{array}$ \\
\hline $\begin{array}{l}\text { Hanna et } \\
\text { al. } 2013\end{array}$ & Canada & $\begin{array}{l}\text { "To explore the } \\
\text { experiences of online } \\
\text { IPE facilitators } \\
\text { in the synchronous } \\
\text { learning environment } \\
\text { of the collaborative } \\
\text { online interprofessional } \\
\text { learning (COIL) pilot } \\
\text { program and } \\
\text { to learn more about the } \\
\text { supports that would } \\
\text { best prepare } \\
\text { facilitators for this } \\
\text { important, yet } \\
\text { challenging role" (p. } \\
\text { 299) }\end{array}$ & $\begin{array}{l}10 \text { synchronous } \\
\text { sessions based on co- } \\
\text { construction of a } \\
\text { patient case over a } 12 \\
\text { week period }\end{array}$ & $\begin{array}{l}\text { Continuing education } \\
\text { interprofessional } \\
\text { learners } \\
\text { From } 8 \text { different } \\
\text { professions } \\
\text { Professions } \\
\text { represented: Dietetics, } \\
\text { Medicine, Nursing, } \\
\text { Occupational Therapy, } \\
\text { Physical Therapy, } \\
\text { Pharmacy, Speech- } \\
\text { language Pathology } \\
\text { and Social Work }\end{array}$ & $\begin{array}{l}\text { Co-facilitating learners } \\
\text { in weekly synchronous } \\
\text { sessions }\end{array}$ & $\begin{array}{l}\text { Written information } \\
\text { training package } \\
\text { Support via weekly } \\
\text { debriefing forms }\end{array}$ & $\begin{array}{l}7 \text { facilitators } \\
\text { Professions } \\
\text { represented: Dental } \\
\text { Hygienist, Health } \\
\text { Promotion Specialist, } \\
\text { Nursing, Pharmacy, } \\
\text { Physiotherapy and } \\
\text { Social Work. }\end{array}$ \\
\hline $\begin{array}{l}\text { Juntunen } \\
\& \\
\text { Heikkinen, } \\
2004\end{array}$ & Finland & $\begin{array}{l}\text { To report "on the } \\
\text { effects of combining } \\
\text { interprofessional }\end{array}$ & $\begin{array}{l}\text { Asynchronous } \\
\text { discussion aimed to } \\
\text { develop a theoretical }\end{array}$ & $\begin{array}{l}150 \text { pre-licensure } \\
\text { students from } 4 \\
\text { professions }\end{array}$ & $\begin{array}{l}\text { Facilitating teams of } \\
\text { students on } \\
\text { asynchronous } \\
\text { discussion boards }\end{array}$ & $\begin{array}{l}\text { No training detail } \\
\text { provided }\end{array}$ & $\begin{array}{l}12 \text { facilitators } \\
\text { Professions } \\
\text { represented: Nursing, }\end{array}$ \\
\hline
\end{tabular}




\begin{tabular}{|c|c|c|c|c|c|c|c|}
\hline & & $\begin{array}{l}\text { education and web- } \\
\text { learning in a module of } \\
15 \text { European Credit } \\
\text { Transfer (ECT) units } \\
\text { for teaching elderly } \\
\text { care” (p. 270) }\end{array}$ & $\begin{array}{l}\text { viewpoint on caring for } \\
\text { the elderly }\end{array}$ & $\begin{array}{l}\text { Professions } \\
\text { represented: } \\
\text { Gerontology, Nursing, } \\
\text { Physiotherapy, and } \\
\text { Social Welfare }\end{array}$ & & $\begin{array}{l}\text { No support detail } \\
\text { provided }\end{array}$ & $\begin{array}{l}\text { Social Welfare and } \\
\text { Rehabilitation Teachers }\end{array}$ \\
\hline $\begin{array}{l}\text { Kropf et } \\
\text { al. } 2015\end{array}$ & USA & $\begin{array}{l}\text { "To examine the } \\
\text { strategies that } \\
\text { gerontology students } \\
\text { used to } \\
\text { facilitate } \\
\text { interprofessional } \\
\text { dialogues within the } \\
\text { VT groups" (p. 376) }\end{array}$ & $\begin{array}{l}\text { Asynchronous } \\
\text { discussion to dialogue } \\
\text { about their practice } \\
\text { experiences }\end{array}$ & $\begin{array}{l}127 \text { pre-licensure } \\
\text { students from } 3 \\
\text { professions } \\
\text { Professions } \\
\text { represented: Medicine, } \\
\text { Nursing and Physician } \\
\text { Assistant }\end{array}$ & $\begin{array}{l}\text { Facilitating teams of } \\
10-11 \text { students in } \\
\text { asynchronous dialogue }\end{array}$ & $\begin{array}{l}\text { Training provided by } \\
\text { course director - no } \\
\text { further details } \\
\text { Support via monthly } \\
\text { meetings with a } \\
\text { supervisor }\end{array}$ & $\begin{array}{l}4 \text { graduate student } \\
\text { facilitators } \\
\text { Professions } \\
\text { represented: Masters of } \\
\text { Gerontology and } \\
\text { Gerontology certificate } \\
\text { students }\end{array}$ \\
\hline $\begin{array}{l}\text { Solomon } \\
\text { \& King } \\
2010\end{array}$ & Canada & $\begin{array}{l}\text { "To evaluate faculty } \\
\text { perceptions of the } \\
\text { barriers and facilitators } \\
\text { to online IPE" (p. 51) }\end{array}$ & $\begin{array}{l}\text { Asynchronous } \\
\text { discussions in modules } \\
\text { ranging in duration } \\
\text { from 3-12 weeks }\end{array}$ & $\begin{array}{l}\text { Pre-licensure students } \\
\text { from } 11 \text { different } \\
\text { professions } \\
\text { Professions not } \\
\text { specified }\end{array}$ & $\begin{array}{l}\text { Facilitating teams of } \\
\text { students on online } \\
\text { asynchronous } \\
\text { discussion boards }\end{array}$ & $\begin{array}{l}\text { Orientation to online } \\
\text { learning and } \\
\text { facilitation } \\
\text { No support detail } \\
\text { provided }\end{array}$ & $\begin{array}{l}11 \text { facilitators } \\
\text { Professions not } \\
\text { specified }\end{array}$ \\
\hline $\begin{array}{l}\text { Waterston } \\
2011\end{array}$ & Canada & $\begin{array}{l}\text { To investigate “online } \\
\text { interaction within a } \\
\text { curriculum } \\
\text { unit at the University } \\
\text { of Toronto, Canada } \\
\text { that included } \\
\text { an interprofessional } \\
\text { case study discussion } \\
\text { in a mixed-mode } \\
\text { (face-to-face and } \\
\text { online) format” (p.272) }\end{array}$ & $\begin{array}{l}\text { Asynchronous } \\
\text { discussions } \\
\text { (supplemented by face } \\
\text { to face interaction) } \\
\text { based on a case study } \\
\text { over a } 4 \text { day period }\end{array}$ & $\begin{array}{l}698 \text { pre-licensure } \\
\text { students from } 6 \\
\text { professions } \\
\text { Professions } \\
\text { represented: Dentistry, } \\
\text { Medicine, Nursing, } \\
\text { Occupational } \\
\text { Therapy, Pharmacy and } \\
\text { Physical Therapy }\end{array}$ & $\begin{array}{l}\text { Facilitating teams of 7- } \\
9 \text { students in face-to } \\
\text { face sessions followed } \\
\text { by optional } \\
\text { contributions to } \\
\text { ongoing asynchronous } \\
\text { discussion boards. }\end{array}$ & $\begin{array}{l}\text { No training detail } \\
\text { provided } \\
\text { No support detail } \\
\text { provided }\end{array}$ & $\begin{array}{l}77 \text { facilitators } \\
\text { Professions not } \\
\text { specified }\end{array}$ \\
\hline
\end{tabular}


